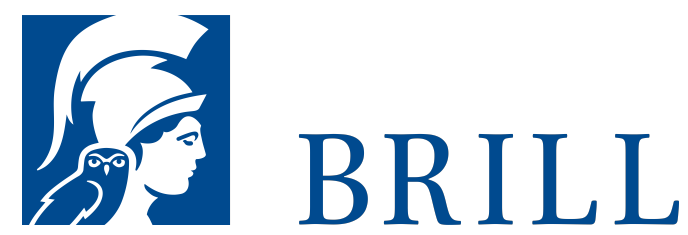

\title{
Die Geburt der Theorie aus dem Instrument
}

Über Bedienung und Bedeutung der antiken Instrumente Groma und Lyra

\section{Author: Nikolaus Thurn}

Die griechische Mathematik kam aus dem Instrument - zu diesem Ergebnis kommt diese Studie, die sich der Rekonstruktion zweier Instrumente und ihrer Funktion widmet. Das Lotinstrument "Groma" (von gr. "Gnomon") sowie die Musikinstrumente Lyra und Kithara lassen sich im 6. vorchristlichen Jahrhundert in Griechenland nachweisen und dürften auf die Entwicklung der Mathematik einen entscheidenden Einfluss genommen haben. Die Studie geht aus von philologischen Überlegungen und bedient sich über archäologische und literarische Belege hinaus auch des eigenen Experiments, das bisher nicht beachtete Lösungswege aufzeigt. Nikolaus Thurn gelingt es einen Zusammenhang zwischen Nautik, Geometrie und Musik herzustellen. Die Entwicklung der griechischen Geometrie und damit die Grundlage der heutigen Mathematik ist auf die genaue Beobachtung von Instrumenten zurückzuführen.

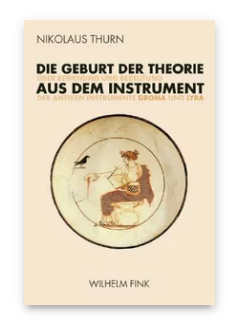

Pages: 228 Seiten, $41 \mathrm{~s} / \mathrm{w}$ Abb.

Language:

German

Subjects:

Cultural History, Literature and Cultural Studies Publisher: Brill | Fink

E-Book (PDF) Released online: 29 Oct 2019 ISBN: $978-3^{-}$ 8467-4474-1 List price USD $\$ 63.00$

Paperback Publication date: 20 Feb 2008 ISBN: $978-3^{-}$ 7705-4474-5 List price USD $\$ 63.00$ 
For more information see brill.com

Order information: Order online at brill.com +44330 333 0049 | customerservices@brill.com Submission information: brill.com/authors

Titles published by Brill | Fink, Brill | mentis or Brill | Schöningh: +49(o)715413279216| brill@brocom.de 